\title{
Coexistence and contamination of vernacular and Latin in Alessandro Braccesi's bilingual tribute to Camilla Saracini. The Siena and Florence of illustrious women and Neoplatonism. ${ }^{1}$
}

In October 1491 the Florentine envoy to Siena, Alessandro Braccesi (1445-1503), composed and dedicated two sonnets in the vernacular and one Latin carmen to Camilla Saracini, the most beautiful girl in the city, who had recently and suddenly become blind. While this may seem only occasional poetry by a lesser-known figure of fifteenth-century Tuscany, a closer look at both the texts and their context reveals that these poems mirror the social and artistic ambitions embedded into Florentine society and the cultural trends of two cities and two languages employed for different purposes. In Siena, where the poems were written, vernacular poetry was the norm, and the production of literary texts in Latin was progressively dying out. Braccesi, however, brought with him a multifaceted Florentine heritage; in his hometown, during the same century, the endorsement of the Tuscan vernacular as the language of literature, culture and philosophy, followed a tortuous path.

Braccesi's work did not stand out among that of his notorious contemporaries. Despite not achieving great success as an intellectual, both his prose and poetry are of great interest, especially in relation to the contamination of Latin and the vernacular. In the specific episode related to Camilla Saracini, it is worth looking into the reasons that moved him to communicate in both languages, when the status of the vernacular was changing side by side with a flourishing Neo-Latin literature.

In this paper, my aim is to first shed light on Braccesi's background and literary ambitions and then to examine the poems for Camilla. In the third and fourth sections I offer my own interpretation of the texts, within the cultural context of Florence and then that of Siena, finally ending with concluding remarks.

\section{Alessandro Braccesi, background and ambitions}

ccording to Kristeller, Braccesi "occupies an important, if not a leading, position among the Florentine humanists of the second half of the fifteenth century,"2 yet the study of his literary works and letters has so far lacked depth. Braccesi, or, as he signed his letters, Alexander Braccius, was born in Florence, became a notary and worked for the Florentine government in a number of temporary offices. He travelled to Rome, Siena, Perugia and Lucca, serving first the Medici family and then the chancery of the Florentine Republic. Thanks to his prominent employers, he became

\footnotetext{
${ }^{1}$ I would like to acknowledge the help of the Renaissance Society of America whose grant allowed me to conduct my research for six weeks in Florence, Italy, and find the archival documents relevant to this paper.

${ }^{2}$ Kristeller 1964, vol. 2, p. 311.
} 
personally acquainted with many well-known officials and intellectuals of the age, such as Bartolomeo Scala, Marsilio Ficino, Angelo Poliziano, Cristoforo Landino, Naldo Naldi and Ugolino Verino. Special mention should be made of his friendships with Benedetto Dei, the eclectic chronicler and traveller, and Nicolò Michelozzi, son of the notorious architect Michelozzo and personal secretary to Lorenzo de' Medici. ${ }^{3}$ Braccesi corresponded widely and his letters are held in a number of libraries. ${ }^{4}$

Braccesi's life was eventful, as Alessandro Perosa wrote in his entry for the Dizionario biografico degli italiani, but has not been duly studied. ${ }^{5}$ His origins could not have been humbler: his father, Rinaldo Braccesi, was, at the age of sixteen, orphan of his father Sandro and caring for his mother Pippa, aged thirty-six. Rinaldo lived in the Quarter of San Giovanni, Gonfalone of Drago, popolo of San Leo. This information is provided by his first catasto record - an early Florentine version of a tax return -, which dates back to 1427 , which also reveals that Rinaldo's family name was not yet Braccesi, but Uccellini. ${ }^{6}$ The Uccellini family appears in another catasto record from 1451. Rinaldo, now a famiglio, servant, aged forty, lived in the house of the family for whom he worked in the popolo of San Lorenzo near the church of San Barnaba, with his mother, aged sixty-five, his wife Sandra twenty-four, his child Alessandro, or Sandro aged five. ${ }^{7}$ The family still lived in San Barnaba in 1458, when Alessandro appears again, now aged thirteen and with a brother, Giovanbattista three. Their father is listed simply as "Rinaldo di Sandro" without any reference to the surname Uccellini, and is now aged forty-seven, his wife Sandra is thirty-four and his mother Madonna Pippa is still alive at the age of seventy. ${ }^{8}$

Now that we have followed the members of the family record by record, it is safe to assume that the Uccellinis became the Braccesis at some point between 1458 and 1480. Their ambition and talent drove them to rent a house near the cathedral of Santa Maria del Fiore, next to the Magistrato dei Pupilli headquarters. The 1480 catasto record begins with these words: "[I], Rinaldo of Alexandro of Sancti Braccesi, live in the popolo of Sancta Maria del Fiore in Florence [...]", 9 albeit clearly in Alessandro's handwriting. It lists Rinaldo, his wife Sandra, Alessandro, Alessandro's brother, Alessandro's wife Lisabetta and their daughters notably named after two classical heroines, Camilla

\footnotetext{
${ }^{3}$ For more on Niccolò Michelozzi and his correspondence, see Isenberg 1982; and on Benedetto Dei, see Orvieto 1969. The most interesting letters that Braccesi wrote to Dei, commenting on events and foreign affairs, are in Florence, Biblioteca Medicea Laurenziana, Ashb. 1841, cass. I, 52-59, cass. II, 37-38.

${ }^{4}$ For a full list of his letters, see Viti 1984.

5 A brief volume on this humanist was published by Bice Agnoletti in 1901 but is now outdated. The most complete information on Braccesi, although relying sometimes on Agnoletti's inaccurate archival research, was collected by Perosa and Kristeller; see Perosa 1943, p. 138 and 1971; Kristeller 1964, pp. 311-315.

${ }^{6}$ Catasto, 79, f. 555v.

${ }^{7}$ Catasto, 714, f. 177.

${ }^{8}$ Catasto, 822, f. 439.

9 “[Io] Rinaldo di Alexandro di Sancti Braccesi habito nel popolo di Sancta Maria del Fiore di Firençe [...]”
} 
and Lucrezia. The family owned some land in the outskirts of the city and, most importantly, both Alessandro and his brother had done well for themselves and become notaries. ${ }^{10}$

Braccesi held a series of temporary positions for the Florentine government from his early twenties, working as a notary all his life. In the 1490s he was appointed, in Alison Brown's words, as "secretary-notary" after Andrea da Foiano with a hybrid function of facilitating Florence's various businesses, including recruiting teaching staff for the Studio (the University of Florence) and, more importantly, of acting as Lorenzo de' Medici's eyes and ears in Siena. ${ }^{11}$ After the fall of the Medici he was employed in other cities, such as Perugia and Lucca, and as an informer for Savonarola in the papal curia, assisting the Florentine ambassador Ricciardo Becchi there, and his successor Domenico Bonsi. Braccesi was elected secretary of the chancery, preceding the appointment of Niccolò Machiavelli, but when Savonarola died Braccesi presumably resumed his job as notary, even though we have no letters from this period to confirm this. He returned to Rome to assist the new Florentine ambassador Giovan Vittorio Soderini in 1502 and died of a sudden fever there on 7 July 1503.

Despite his efforts and wide literary production, which is listed in detail below, Braccesi struggled to emerge as a poet during his time, even when he attempted to find other patrons than the Medici. The drive to emerge socially and artistically that belonged to Braccesi and his family affected him even after death, when his grandson, the poet Agnolo Firenzuola, commissioned a gravestone for the his burial place in the church of Santa Prassede in Rome, which included a bas-relief depicting the coats of arms of the noble and prestigious Florentine Bracci family, completely unrelated to the Braccesi but in the sound of their name.

Braccesi's literary production seems divided equally between Latin and the vernacular. He wrote a collection of carmina, which were further divided into amorum libellus, secundus liber epistolarum ad amicos and epigrammatum libellus, which went through several revisions. ${ }^{12}$ The first version of this collection, published by 1473, was dedicated to the Florentine merchant Francesco Sassetti and the last version, released some thirteen years later, was dedicated to Guidobaldo da Montefeltro, the Duke of Urbino. ${ }^{13}$ His vernacular poems are also notable and can be divided into two main genres, love poetry and comic poetry. The love poems were composed and organized into a canzoniere entitled amor libellus, a sylloge that imitates Petrarch's Rerum vulgarium fragmenta although with some original features. ${ }^{14}$ The comic production, on the other hand, is mostly alla burchia, i.e. the poems are modelled on the poetry of the fifteenth-century master of comic-realism, Domenico di

\footnotetext{
${ }^{10}$ Catasto, 1017, f. 419. This record and that of 1457 are mentioned by Perosa 1971 who quotes Agnoletti.

${ }^{11}$ Brown 2011, p. 41.

${ }^{12}$ For the full ecdotic analysis, see Perosa 1984.

13 Perosa 1984, pp. 139-149.

${ }^{14}$ Braccesi 1983, pp. IX-XXX.
} 
Giovanni also known as Burchiello. Despite the desparaging words we find in the epigrammatum libellus ("Burchiello, who writes truly empty poems [...]"), ${ }^{15}$ Braccesi wrote more than two hundred poems alla burchia, often achieving excellent results. ${ }^{16}$ A collection which joined the first version of the love and comic poems, transcribed in a parchment manuscript now kept at the Vatican Library, was a gift to Giovanni, Count of Carpegna, the feudal lord of an area in Montefeltro under the protection of the Medici from the second half of the fifteenth century. ${ }^{17}$ The second version of the amorum libellus dated around 1487, however, is dedicated to Guidobaldo da Montefeltro, like the Latin poems from the same period.

What Braccesi managed to print in his lifetime were only his translations of others from Latin into the vernacular; volumes which enjoyed wide circulation and which stayed in print for nearly two centuries: Pius II's Historia de duobus amantibus and Appian's Roman history from Pier Candido Decembrio's translation from Greek. The first, a translation of the tale of two lovers is relevant to this study for two reasons. First, the connection with the city of Siena before Braccesi was sent there in 1491. The Historia, written in Vienna in 1444 by the illustrious Sienese Enea Silvio Piccolomini, is set in the hometown of the future pope Pius II. This translation went through two revisions, the first dated around 1478-1479, and the second printed between 1481 and 1483 in Milan by Leonardus Pachel and Uldericus Scinzenzeler. ${ }^{18}$ Braccesi's is no mere translation, but a fresh rendition of the tale of Euryalus and Lucretia: the form changes into a prosimetrum, as the prose is interspersed with many of Braccesi's Petrarchan poems, while the content is affected too, especially by the gift of a happy ending. This approach to translation from Latin into the vernacular is the sign of a mentality that went beyond the intention of making a text available to those who could not afford to learn Latin, as was the case with some intellectuals of the age who translated their own works for this purpose, for example Marsilio Ficino with his De amore and De christiana religione. ${ }^{19}$ Braccesi's Historia bears the noble heritage of Piccolomini's Latin, but it is a work in its own right, an entirely new tale that acquires fresh vigour from the expressivity of the vernacular. $^{20}$

Finally, Braccesi's favourable attitude towards the coexistence and contamination of Latin and the vernacular is very clear from the fact that he translated one of his own poems from the vernacular

\footnotetext{
${ }^{15}$ Braccesi followed a similar statement by Cristoforo Landino, who deeply influenced his poetic style in Latin. "I send you the numerous poems of Burchiello" he writes in his Carmina, liber secundus, XXVIII, "read them. And what are they? You will read nothing." See Landino 1939, p. 70: "Plurima mitto tibi tonsoris carmina Burchi;/ haec lege. Sed quid tum? Legeris inde nihil". Braccesi 1943, p. 105: "Burchius Aoniis migravit collibus alter/ qui quoque nimirum carmen inane facit [...]."

${ }^{16}$ Signoriello, Satire of philosophy, pp. 118-140.

${ }^{17}$ Rome, Biblioteca Apostolica Vaticana, 10681.

${ }^{18}$ Viti 1982, pp. 49-50.

${ }^{19}$ Bertolini 2015, pp. 206-207.

${ }^{20}$ See Viti 1982, pp. 67-68.
} 
canzoniere, "Come incaüto pesce correr sòle", into Latin, and included it in his amorum libellus (VI, "Ut solet incautus fatales piscis ad escas"). The fact that there are only a few occurrences of self-translation in fifteenth-century Florence - and that only prose - clearly puts Braccesi into a category of his own. ${ }^{21}$

The poems written to honour Camilla Saracini, which have never been studied, are another case in point. Braccesi had been in Siena for two months when he seized an occasio caecitatis and composed two poems in lamentation of Camilla's blindness. These he included in four letters to four different people, which explained the circumstances of the event: on 28 October 1491 to Lorenzo de' Medici; ${ }^{22}$ on 29 November to Bartolomeo Scala, the chancellor of Florence; ${ }^{23}$ to Niccolò Michelozzi, the personal secretary of Lorenzo, on 28 November, ${ }^{24}$ to Francesco Gaddi, the secretary of the Otto di Pratica and Braccesi's direct supervisor in this mission, on 4 December. ${ }^{25}$ The poems were allegedly sent to each of them and the two vernacular sonnets were written in response to one dedicated to Camilla by Bartolomeo Scala, now lost, as we can infer from the letter written to the chancellor: ${ }^{26}$

I know you will wonder and perhaps also barely tolerate the fact that I put off until today replying to these letters, which you wrote to me so kindly and intimately, with some poems that you wrote for Camilla Saracini. This undoubtedly happened because of the weakness of my intellect and the poverty of my native language, as I could barely find and explain what I think to you, such an authoritative and learned man, or barely do the minimum, and I strongly doubt it would be enough, lest I offend your very delicate ears with my incompetence and ignorance. Nevertheless, I preferred to look ridiculous rather than being criticised for my courtesy.

\footnotetext{
${ }^{21}$ See the list drafted in Bertolini 2015, pp. 213-214.

${ }^{22}$ SDO, 27, ff. 38v-39.

${ }^{23}$ SDO, 27, ff. 56-56v; L, ff. 71-72, transcribed by Perosa in Braccesi 1943, p. 156.

${ }^{24}$ L, ff. 76-76v (this copy of the letter is not mentioned in the list by Viti (1984), p. 392; SDO, 27, 53r-54v; New York, Pierpont Morgan Library, F. 132. This is the copy of the letter that Michelozzi actually received and that Viti mentions as "Coll. Bocchi Bianchi (aut. datata «28 nov. 1491)". This letter belonged to a corpus owned by the baroness Maria Clorinda De Franceschi Bocchi Bianchi, who gave them to the bibliophile Tammaro de Marinis in 1970. De Marinis published the letters - see De Marinis-Perosa 1970, p. 43 - and his heirs gave the letters back to the Bocchi Bianchi family. The letters, however, were scattered and found partly at the Pierpont Morgan Library in New York and partly in London at Christie's, where they were impounded and given to the Biblioteca Nazionale Centrale in Florence. See De Franceschi, famiglia, ed. E. Insabato, S. Trovato, first appeared online 2012, accessed 26 November 2016 http://siusa.archivi.beniculturali.it/cgi-bin/pagina.pl?TipoPag=comparc \&Chiave=126948.

${ }^{25}$ SDO, 27, ff. 58-58v; L, f. 75, transcribed by Perosa in Braccesi 1943, pp. 158-159. This manuscript is described by Perosa in Braccesi 1943, pp. XVII-XXII.

${ }^{26}$ L, f. 71. "Scio miraberis et forte etiam moleste feres quod distulerim ad hanc usque diem respondere his litteris quas ad me una cum rithmis a te editis in Camillam Saracinam scripsisti tam humaniter tamque familiariter. Primum quidem accidit hoc imbecillitate ingenii mei deinde inopia sermonis patrij cum vix potuerim et invenire et explicare quod putarem homini tibi gravissimo doctissimoque vel minima in parte posse facere, satis addubitans vehementer, ne delicatissimas aures tuas meis ineptijs ac ruditate offenderem."
} 
In his daily life and duties, Braccesi used both Latin and the vernacular with precise distinction, as did all functionaries of his time: Latin for notarial documents ${ }^{27}$ and the vernacular in correspondence, both personal and professional. Most of his few letters in Latin were addressed to Michelozzi, but the vernacular was the default choice for all others, even to his employer in 1491, Lorenzo de' Medici. In writing the letters about Camilla's illness, however, Braccesi chose ornate Latin: was he trying to impress his superiors and peers back in Florence? In his letter to Francesco Gaddi, Braccesi mentions the fact that he had written to Lorenzo de' Medici in October, perhaps implicitly asking him if there had been any reaction: ${ }^{28}$

I am delighted that I wrote to Lorenzo de' Medici that, having Camilla Saracina lost her sight, there is hope that at some point she will fully recover her vision; the same happens to the sun when it undergoes an eclipse, once it overcomes the eclipse's gloom, it appears the same as it was before, and it shines on us with its usual brightness.

On the one hand, the use of Latin, so uncommon in his secretarial duties and employed only in the letters about Camilla, sets a specific register for Braccesi's illustrious interlocutors in Florence. On the other hand, however, this small corpus of texts includes two vernacular sonnets that are more than just a reply to Bartolomeo Scala; they pay homage to the Senese tradition of vernacular poetry. I will now explore these two sides of the matter and the interaction between two languages, two cities and their cultural legacy in the Quattrocento.

\section{The poems}

Braccesi first wrote the letters about Camilla in a draft version, now at the Archivio di Stato in Florence, ${ }^{29}$ and then transcribed three of them, leaving out the first one to Lorenzo de' Medici, in an autograph codex now in Florence, Biblioteca Medicea Laurenziana, Laur. Plut. 91 sup. 41, (ff. 72v73), hereby referred to as " $\mathrm{L}$ ". ${ }^{30}$ One version of the poems for Camilla survived in this manuscript, following the letter to Gaddi. Another version of the poems is in the copy of the letter to Michelozzi that was actually sent and is now in New York, Pierpont Morgan Library, F. 132, hereby referred to

\footnotetext{
${ }^{27}$ Florence, Archivio di Stato, Notarile antecosimiano 3331-3339. Note that Perosa 1971 still quotes the old classmark, Notarile B 2317-2325.

${ }^{28}$ SDO, f. 75: "Gaudeo quod, ita scripserim ad Laurentium Medicem Camillam Saracinam oculorum visum amisisse, ut spe non careas futurum esse quin illa possit aliquando videndi recuperare vim pristinam, quemadmodum etiam soli defectum patienti evenit, qui sublato eclipsis incommodo, idem qui ante eclipsim fuerit appareat, atque ad nos consuetum splendorem emittat."

${ }^{29} \mathrm{SDO}$.

${ }^{30}$ Ff. 72v-73, transcribed by Perosa in Braccesi, Carmina, pp. 140-141, 157-158.
} 
as "N". ${ }^{31} \mathrm{~L}$ was written and kept for personal use by the author, and therefore we can assume that the very last variations to the texts are found here. Below, I transcribe the texts as found in L, and N's variations in the apparatus.

1 Ponat Amor pharetram moestus frangatque sagictas, ac tenera plangat pectora nuda manu, et doleat tristis passis Citherea capillis, delitias ploret casta Minerva suas;

5 cesset et omnis honor, cultus valeatque Senensis, et matrona simul lugeat atque nurus, usque puellarum coetus, quin tota iuventus, ${ }^{32}$ certatim lachrymis abluat ora gemens: heu, Saracina, decus splendorque et gloria formae,

10 pulchrius in vestra qua fuit urbe nihil, infoelix visu capta est, miserabile dictu; sic ne vacare deos, heu, pietate decet? Quidnam erat in terris oculis formosius huius? Quid magis his poterat par fore syderibus?

15 Hos obscura tamen caligo ac densa recondit, nec caelum aut terras posse videre sinit.

Quod scelus auditum maius, quod saevius isto? Quid Sena, quid potuit tristius esse tibi?

Sed maior iactura fuit tua, saeve Cupido:

20 huius erant oculi retia nanque tua. Nil tibi nunc superest, quo vincula nectere possis, ut prius, in iuvenes, quos Sena pulchra fovet. Nunc et abest omnis penitus iucunda venustas, nunc reliqua est Veneri gratia nulla deae,

25 nunc quoque moeret iners, artes quae docta Minervae callet, quod tenebrae lumina clausa tenent.

Ergo, Cupido simul Venus et Bellona parenti fundite devotas, heu, sine fine preces, lumina restituat donec formosa Camillae, hanc, prius ut poterat, posse videre sinat.

15 Hos... recondite: N Corripit obducta tamen hos ceu nocte caligo

25 Minervae : N Minerva

26 quod... clausa: $\mathrm{N}$ at heu tenebrae lumina diva

28 heu: $\mathrm{N}$ nunc

29 formosa: N purgata

30 posse: $\mathrm{N}$ queque

II.

\footnotetext{
${ }^{31}$ Transcribed in De Marinis-Perosa 1970, pp. 47-49.

${ }^{32}$ Unlike Perosa, who transcribed "inventus" I read "iuventus" as in MS N.
} 
1 Piangete donne belle, et chon voi Amore poi chè perduto havete il vostro sole de duo begli ochi, onde 'l mondo si dole e 'l celo anchora par ne mostri dolore,

5 poi che la luce che faceva honore all'altre stelle, più chome far sole, non illustra la terra et la suo mole chon la virtù del suo grande splendore.

Manchati sono a Phebo e' raçi suoi;

10 Amore ha perso l'arme e la baldanza;

Invidia ha spento il fior d'ogni belleça.

Pietoso Giove, adunque, se tu vuoi in una opra mostrare ogni possanza rendi a' begli ochi la sua gran dolceça.

N Senensibus puellis

3 de: $\mathrm{N}$ ne'

4 anchora: $\mathrm{N}$ anchor

III.

1 Ben puoi dolerti, Siena, del mal fato che 'l terreste tuo sole ha in te spento et privo ti ha d'un sì bello ornamento che chi el vedie se ne tenea beato.

5 Chome esser può che tanto mal sie nato che duo begli ochi quai sença fomento d'amor nissun potie ghuardare intento chondocti sieno in sì misero stato?

O la lor luce Phebo ha convertito

10 ne' raçi suoi per duplichar suo força che se gli è vero ha da temer la terra.

O per suo dignità s'è risentito che vedendo suo lume in terra amorça un altro sole in tenebre lo serra.

N Ad Senensem urbem

9 lor: $\mathrm{N}$ suo

13 lume: $\mathrm{N}$ luce 
Predictably, the author places emphasis on every figure of speech related to Camilla's eyes. In terms of metaphor, her eyes were like the Sun that shone over Siena and the whole world, especially in the vernacular texts (II.3, II.7, III.2, III.15) or like the most beautiful stars that, fading, left darkness in the sky - in the Latin carmen (I.14-16). In both vernacular and Latin poetry, comparing a woman's eyes to the sun and the stars is topical and needs no further exploration here. What is far less common is finding literary sources describing blindness with metaphors or similes. Blindness as a metaphor, however, is not uncommon in philosophy, which is the point of departure for investigating Braccesi's bond with Florence. ${ }^{33}$

\section{Florence and Neoplatonism}

In his letters, Braccesi offers a sort of self-commentary to his poems. The letter to Lorenzo de' Medici, possibly the most interesting, is unfortunately the least readable. It has survived only in its draft copy, which was scribbled on and crossed out in most parts and therefore largely unintelligible, with the exception of isolated sentences, like in a marginal note, where we read: "The Sienese sun suffered and eclipse". ${ }^{34}$ This simile is also in the letter to Gaddi, in which Braccesi expresses the wish that Camilla's condition is similar to that of an eclipse, whereby the sun is only temporarily obscured by the moon: ${ }^{35}$

I would not have denied that you were moved by an excellent reason, when it is obvious that the sun itself during an eclipse does not suffer, but cheats our sight, because the moon, drawing close to the sun, blocks the light of the sun from our eyes with its mass. The sun endures the eclipse for as long as the moon covers it.

This very unusual metaphor is in fact a quotation from Macrobius' Commentarii in somnium Scipionis in a passage explaining first lunar and then solar ecplise I, 15, 13-14: ${ }^{36}$

\footnotetext{
33 "Blindness is not a central theme in Renaissance imagery. Neither in literature nor in the visual art is much attention paid to the sightless person. To the student of Renaissance culture, particularly of Italy during the fifteenth and sixteenth centuries, this seeming lack of interest in the blind and their world shaped by this defect, remains a puzzle. We hardly know of a period in which vision was so highly valued as in the Renaissance." Barasch 2001, p. 115.

34 "Senensis sol eclypsim patitur." Unless I state otherwise, translations are my own.

${ }^{35}$ L, ff. 75-75v: "Non negaverim fuisse te optima ratione adductum, cum manifestum sit solem (75v) ipsum in difectu nil pati, sed nostrum fraudari aspectum, cum luna, soli succedens, obiectu suo lumen eius ab oculis nostris nostris repellat: et quamdiu soli adversa sit, tamdiu ille patiatur eclipsim."

36 "Sic enim evenit ut aut lunae contra solem positae ad mutuandum ab eo solitum lumen sub eadem inventus linea terrae conus obsistat aut soli ipsa succedens obiectu suo ab humano aspectu lumen eius repellat. In defectu ergo sol ipse nil patitur sed noster fraudatur aspectus, luna vero circa proprium defectum laborat non accipiendo solis lumen, cuius beneficio noctem colorat.
} 
For it happens that when the moon borrows from the sun the usual light, being opposite to the sun, its trajectory meets the cone [of shade] of the earth; while in the other case, when the moon overtakes the sun, by its interposition it deprives the earth of the sun's light. Therefore, during the eclipse, the sun itself does not suffer but our sight is cheated and, in fact, the moon suffers, not receiving the sun's light, by which it colours the night.

The eyes of Camilla might still be rescued by divine intervention and indeed might not have been hurt at all, just as the sun is only temporarily obscured by the shadow projected by the moon during an eclipse. The precision of this description is not common in lyric poetry and this could be the reason that moved Braccesi to leave it in the letters. Comic poetry, nonetheless, was an entirely different matter, and Braccesi as a comic poet felt clearly at ease with all other subjects and styles, not exclusively satirical. He expressed interest, for example, in the explanation of natural phenomena, as when he quotes Macrobius. In his corpus of comic poems in the vernacular, for example, the poem Grandine è pioggia in aer congelata ("Hailstones are rain frozen in the air") explains in only fourteen lines the nature of hailstones: ${ }^{37}$

Grandine è pioggia in aer congelata dalla forza del vento, e è vapore humido e freddo, o vogliam dire umore, dal caldo spinto in nube più gelata.

5 Questa cagione dal Philosopho è data: che ' 1 freddo, in aer fuggendo il calore, alla parte ricorre interiore della nube, dov'è più condensata.

E quello humor, che nella nube trova,

10 in tondi serra di tanta freddeza che ciò che toca da morzar ${ }^{38}$ fa prova.

La state più che l'inverno si impeza ${ }^{39}$ perché del freddo allor la virtù nova chiamata dal calor s'unisce en treza. ${ }^{40}$

\footnotetext{
${ }^{37}$ Florence, Biblioteca Riccardiana, 2725, f. 105v. See my commentary in Signoriello 2014, p. 122. This explanation is found in Aristotle, Meteorology, I, 12, and could have been found by Braccesi in several commentaries, for example, those of Albertus Magnus, Thomas Aquinas and Themon Judaeus; see Martin 2011, p. 18. See also the vernacular version by Cecco d'Ascoli in his poem Acerba: Stabili 2002, I, 7.13-24, p. 40: "Ma qui pò dubitar[e] 1'alma gentile:/ nel tempo caldo com[o] si forma il ghiazzo,/ e sprivase nel suo tempo simìle./ La spera che ten[e] focho in sua virtute/ dico che fuga il fredo col suo brazzo/ e tienlo in unità con sue ferute./ Così de focho li raggi reflessi/ inverso l'aire de la nostra terra/ per l'orizonte essendo conessi,/ e quando regie Chancro e poi Leone,/ assai più fredo nel mezo se serra:/ però il gh $<\mathrm{i}>$ azo piove la stagione."

38 “morzar": Battaglia, vol. 10, p. 976: "ant. spegnere, smorzare (la luce); estinguere (il calore)."

39 "impeza": alternative form of impecia from impeciare, see Battaglia, vol. 7, p. 420, s.v. "impeciare": "invischiarsi; restare impaniato, irretito."
} 
15 E nel verno si speza

e per l'aer si sparge disunita,

che fa la neve spesso a poggi unita.

In this sonnet, Braccesi employs Aristotle's theory quite literally, without adding any metaphor and a resulting dry and didactic. This genre was not new: Dante's Commedia inspired a large number of didactic poems written in terza rima during the thirteenth century. Didactic poetry, although it was never matched to sonnet form before Braccesi, remained popular during the fifteenth century, displaying curiosity about natural philosophy along with encyclopaedic aims. ${ }^{41}$ Nevertheless, this genre was exclusively vernacular and it never triggered a Neo-Latin equivalent.

The curiosity for natural philosophy might not alone fully justify the presence of Macrobius's Commentarii in Somnium Scipionis in Braccesi's letters, especially considering the time, the second half of the fifteenth century, and the place where these letters were read, Florence. The choice of Macrobius is not as plain as that of Aristotle: Macrobius's commentary was a Neoplatonic text that had been read and referred to by Marsilio Ficino, who, in 1491, was still the most prominent philosopher. Even though the poems for Camilla do not have a Neoplatonic message per se, the significance of her eyes and the unusual eclipse metaphor might hint at something that goes beyond the literal meaning and traditional figures of speech about a woman's eyes.

Before exploring the Neoplatonic aspect of the texts, it is useful to compare them to a sonnet by Braccesi in order to appreciate the difference between a Petrarchan, indeed almost standard, lyric poem and the verses for Camilla. Braccesi was not immune to the re-use of traditional metaphors describing the eyes, the look and the effects that these produced on him in his love canzoniere, which include a sonnet that touches upon the theme of blindness (VI): ${ }^{42}$

1 Phebo, da invidia preso e maraviglia, veggendo in terra una sì chiara luce che più che 'l sole a mezzo dì reluce quando tra nube e nube s'assottiglia,

5 da ira tinto e con turbate ciglia, avanti a sì belli ochi si conduce e con inganno pose un ferro truce in quella man ch'al marmo s'assomiglia.

\footnotetext{
40 "Trezza" is treccia, "plait." Other examples of the affrication occurs in Braccesi 1983, I.37-38, p. 4 and 71.7-8, p. 73: "Son le sue treze bionde/ l'esca della mia fiamma"; "quella bionda treza/ e 'l bel volto ch'a morte mi conduce" "presto mutare/ suolsi in altro color la bionda treza."

${ }^{41}$ Ciociola, p. 413.

${ }^{42}$ Braccesi 1983, p. 7.
} 
Poi nella adorna veste un nodo strinse

se non ch'allor Dïana pietà vinse tanto della sua amata nynpha diva, che 'l ferro dal suo corso fece tòrre.

This sonnet and those for Camilla share the image of the envious Phoebus and the emphasis on the description of the light. No attention, however, is drawn here to the eyes themselves and there is no mention of the rays of light coming directly from the eyes of the woman saved by Diana, who is almost secondary compared to the gods who decide her fate.

Camilla's eyes receive an entirely different treatment. In the texts there is an oddity that stands out, that is the idea that a young woman might not be virtuous or beautiful even if blind, considering that, after all, Camilla was still alive and presumably honourable. From a Ficinian perspective however, having lost her sight, Camilla has lost her chance to reach for the divine. In his treatise $D e$ amore, a commentary on Plato's Symposium completed by 1469 and translated into the vernacular in 1474, Ficino explained at length, in particular in the sixth oration, how love is nothing but desire for beauty and how the first step to reach for the divine is always taken via the observation of physical beauty, which is seen through the eyes: ${ }^{43}$

The gates of the soul are the eyes and the ears, because many things pass to the soul through them, and the emotions and habits of the soul clearly show in them. Lovers spend most of their time in looking and listening to their loved one, and they are rarely attentive, and their mind wanders often to their eyes and ears.

In Ficino's metaphorical system, it is the sun, i.e. God, which both generates the eyes and allows them to see beauty. To describe this process, Ficino uses the concept of the rays of the sun, which originate from God, reach the lover and then go back to God: ${ }^{44}$

\footnotetext{
${ }^{43}$ Ficino 1987, p. 140: "Le porte dell'animo sono gli occhi e gli orecchi, perché per questi molte cose entrano nell'animo, e gli affecti e costumi dell'animo chiaramente per gli occhi si manifestano. Gl'innamorati consumano el più del tempo nel badare con gli occhi e con gli orecchi intorno allo amato, e rade volte la mente loro in sé si raccoglie, vagando spesso per gli occhi e per gli orecchi."

44 Ficino 1987, p. 143: "Questo tanto dono nasce dalla copia che è padre dello Amore, perché el razzo della bellezza, che è copia e padre d'Amore, ha questa forza, che'e' si riflecte quivi ond'e' venne, e riflectendosi tira seco l'amante. Certamente questo razzo, disceso prima da Dio, e poi passando nell'angelo e nell'anima come per materie di vetro, e dall'anima nel corpo, preparato a ricevere tale razzo, facilmente passando, da esso corpo formoso traluce fuori maxime per gli occhi come per transparenti finestre, e subito vola per aria, e penetrando gli occhi dell'uomo che bada ferisce l'anima, accende l'appetito."
} 
This great gift generates from richness, that is the origin of Love, because the ray of beauty, that is richness and origins Love, has this power, which is reflecting back to the place where it came, and by reflecting pulls back the lover. Certainly this ray, coming down first from God, and then going through the angel and the soul as if they were glass, and from the soul into the body, which is ready to receive this ray, passing easily, from this full body shines brightly outside through the eyes as if they were clear windows, and immediately flies in the air, and penetrating the eyes of the attentive man, it hits his soul, generating desire.

Braccesi might have referred to this concept when mentioning Phoebus' rays, "razi" (II.9, III.10): rays that Camilla has lost. This would not be new to Neoplatonism, as Ficino himself wrote in a letter to thank him for an epigram in his honour: ${ }^{45}$

Our Plato, in the dialogue entitled Ion, considers as the divine music and deeply imbued with the frenzy of Muses only songs, which are accompanied by the music of men and the singer with the listeners somehow incite in frenzy. Yesterday, Alessandro wrote some songs to Marsilio that were truly of this kind, and soon my cithara proved it to many listeners.

Moreover, in his love canzoniere Braccesi had already focused on Neoplatonic themes filtered through Lorenzo de' Medici's Comento de' miei sonetti. For instance, Braccesi developed in his poems the theme of the lover becoming the object of his love (LIII). Although this theme had been developed in courtly poetry, Ficino described it in his De amore (II, VIII) and Lorenzo repeated it in his Comento (XXX). Another theme used by Braccesi (LIV), one that has a resonance with Lorenzo's work (III, XXXI, XXXVII), is the lover's dichotomy between pain and pleasure. There are more deeply rooted ties to Lorenzo such as the distance of the loved one experienced as deprivation by absence (LXIII-LXX), a Petrarchan theme that later became humanistic, and an

\footnotetext{
45 "Plato noster in dialogo, qui Ion inscribitur, carmina illa solum divina musica Musarumque furore infusa penitus existimat, quae cum musica humana cantantur et cantorem ipsum et audientes quodammodo concitant in furorem. Alexandri vero carmina heri ad Marsilium scripta esse talia, mox cithara mea plurimis audientibus comprobavit."

A more explicit admiration for Ficino and his philosophy is found in Braccesi's Epigrammatum libellus (XII). One of these letters is addressed to Ficino, who is described in quite flattering words: "[...] you shall have, believe me, everlasting fame. This is because Britons read your works, which have already reached them; people from Tomi and Sabaeans read your works, and I do not even mention our people: your name is constantly in their mouths and they bring you to heavens with their praises. But why do I attempt to praise you with such a weak pen? Why do I sing this with hoarse verses? For this topic needs a sweeter and greater speech, and it must be better celebrated by a refined lyre. Nevertheless, I have written these things inflamed by a great love: grant indulgence, if you do not read a worthy poem." Braccesi 1943, p. 85: “[...] ac tibi, crede mihi, fama peremnis erit;/scripta legunt quoniam tua iam vulgata Britanni, / illa thomitani gensque Sabaea legunt,/ ut taceam nostros, quorum versaris in ore/ et qui te in caelum laudibus usque ferunt./ Ast ego cur tenui calamo tibi dicere laudes/ tento? Quid haec raucis versibus ipse cano?/ Dulcius eloquium nanque haec maiusque requirunt,/ et magis exculta sunt celebranda lyra;/ haec ego sed magno succensus amore notavi:/ da veniam, nisi te carmina digna leges."
} 
overlap between erotic and theological themes - a trope common to both Lorenzo's Comento and the final section of Braccesi's collection (LXX-LV). ${ }^{46}$ Braccesi, according to the scholar Franca Magnani, had been at some point a student of Cristoforo Landino but, as this cursory survey of his works might suggest, Neoplatonism in the works of Lorenzo de' Medici and Ficino may well have been an important influence.

\section{Siena and its illustrious women}

Braccesi, despite his attempts to promote his poetry in Florence, did not overlook the place where he was writing and his local audience. The literary world in Siena was quite different from that of Florence. As Carrai pointed out, if in the first half of the fifteenth century we encounter the names of eminent Neolatin poets such as Panormita, Marrasio, Francesco Patrizi and Enea Silvio Piccolomini, during the second half there was virtually no relevant Latin poetry, with the exception of the oratory poetry of Agostino Dati and the Bucolicum carmen by Fosco Paracleto da Corneto, dedicated to Enea Silvio Piccolomini. The real protagonist in literary Siena half way through the fifteenth century is the vernacular, starting with Francesco Arzocchi, who, at the beginning of the century, gave way to Tuscan pastoral poetry. The latter became a Sienese speciality that was exported as far as the Veneto and Naples. ${ }^{47}$

Pastoral poetry, however, was not the only focus of Sienese literary circles. Throughout the century a tradition of praise of illustrious women took several forms and the three main names in this genre were Bernardo Lapini, better known by his pseudonym Ilicino, Benedetto da Cingoli and Niccolò Angeli, all of whom taught at the Studio in Siena during the second half of the century. This is a genealogy of Sienese women praised during the two decades between the 1460s and the $1470 \mathrm{~s}:{ }^{48}$

- Onorata Orsini, who lived between 1435 and 1458, was the subject of Vita di madonna Onorata, a biography in the form of a prosimetrum written by Ilicino between 1469 and $1470 ;^{49}$

- Bianca Saracini, Onorata Orsini's daughter, born in 1453 and subject of a capitolo ternario written in the 1460 s by Benedetto da Cingoli. The same author dedicated to her some Epigrammata in Blancam, published in 1503 and $1511 ;^{50}$

- Ginevra di Bartolomeo Luti, for whom Bernardo Ilicino wrote a small canzoniere and an experimental work in prose called Somnium; ${ }^{51}$

\footnotetext{
${ }^{46}$ Braccesi 1983, pp. XXXII-XXXIX.

${ }^{47}$ Carrai Enea Silvio Piccolomini, pp. 32-36; Carrai, Benedetto da Cingoli, pp. 43-44.

${ }^{48}$ On this topic see Cracolici 2009, Agiografie laiche.

${ }^{49}$ See the dating in Carrai, Benedetto da Cingoli, p. 45. Lapini 1843.

${ }^{50}$ See Carrai, Benedetto da Cingoli, p. 47; Benedetto da Cingoli 1503 and Bendetto da Cingoli 1511.
} 
- Caterina Orlandi, dedicatee of another canzoniere by Benedetto da Cingoli; ${ }^{52}$

- Francesca Benassai or Cervia because of her senhal, a deer, praised by both Bernardo Ilicino and Angeli. ${ }^{53}$

The reason why this sequence of women and poems forms a proper tradition, rather than being simply a literary trend of praising illustrious women, resides in the relationship between these women and the works dedicated to them, and specifically in the case of Onorata, Bianca and Ginevra.

This list has been arranged in chronological order by birth, when, in fact, the first praise written was the capitolo ternario for Bianca, dated by Carrai to some point during the 1460 s, when Ilicino taught medicine at the Studio in Siena, before he moved to Ferrara. This long capitolo for Bianca can be found in its entirety in the 1503 edition printed in Rome by Johann Besicken; part of it is in Florence, manuscript Palatino 211 at the National Library of Florence, with an illumination by Francesco di Giorgio Martini and Liberale da Verona. ${ }^{54}$ The portrait depicts Bianca Saracini holding a snowball, (symbolising her purity), aloft the city of Siena. The events narrated in the capitolo are briefly the following. As Bernardo wanders in the outskirts of Siena, lamenting the impossibility of writing a poem for Bianca, a woman too perfect to be described with due credit by his intellect, Apollo himself appears explaining the reason for such ineffability. Bianca is simply a gift from the gods of Olympus, who, in an act of generosity, decided to give men a gift so perfect that it might rescue them from their misery.

Some years later, Benedetto da Cingoli wrote the biographical prosimetrum entitled Vita di madonna Onorata, an homage to Onorata Orsini. Onorata, despite her very short life, was an model of absolute virtue for both men and women in Siena, and so she was loved by every citizen. By recounting her life, Benedetto refers to events that happened from 35 to 15 years earlier, as Onorata was the mother of Bianca and wife of Iacomo Saracini.

Finally, Ginevra Luti, like Onorata a "mirror, glory and honour of all living women", ${ }^{55}$ is the main character of a work that seems to combine the Capitolo for Bianca and Onorata's biography. It is yet another prosimetrum, this time by Ilicino, who describes a dream he had with historical characters and gods arguing for or against Love and Modesty; and, of course, Ginevra as the only living being capable of reconciling the two.

\footnotetext{
${ }^{51}$ Cracolici, L'etopea di Ginevra.

${ }^{52}$ See Carrai, Benedetto da Cingoli, p. 47; Carrai, Un commento quattrocentesco, pp. 54-55.

${ }^{53}$ See more details on both in Carrai, Benedetto da Cingoli, p. 45.

${ }^{54}$ Bellosi 1993, p. 262.

55 "Spechio, gloria et honore di tutte le donne viventi."
} 
Stefano Cracolici has correctly defined this sequence of praises for illustrious women as a "secular hagiography" 56 even though there is another point deserving attention: the praise of these women exists only in relation to the city of Siena. Both Ilicino and Benedetto da Cingoli emphasise their role in Siena, as these women contributed to the prestige of their city.

It is no coincidence that Braccesi chose to honour a female member of the Saracini family, like Onorata and her daughter Bianca. Tellingly, Braccesi addressed Siena and its citizens quite vehemently in all three poems for Camilla. Piangete donne belle, et chon voi amore is directly addressed to Camilla's peers. In Ben puoi, Sena, dolerti del mal fato, the city itself is addressed and Camilla's eyes as its sun (III.1-3). In the carmen it is explicitly stated that Camilla's honour and beauty were the best in all of Siena: "Heu, Saracina, decus splendorque et gloria formae/ pulchrius in vestra qua fuit urbe nihil'. And again, the personification of Siena mourns the loss of someone even more powerful than Cupid (I.18-20). Camilla's ancestor Bianca, according to the art historian Marilena Caciorgna, symbolizes the virtues and qualities of the city of Siena itself and her descendant Camilla plays an identical role in the personification of Siena. ${ }^{57}$

\section{Conclusion}

Nearly halfway through the century, in 1441, the polymath Leon Battista Alberti organised a certame coronario, i.e. a juried competition among a select group of poets whose submissions on the topic of friendship were to demonstrate the capability of the vernacular to rival Latin with respect to specific parameters. Notwithstanding the uncertain results of the competition, the event was a landmark in the history of the vernacular. By the 1460s, the efforts of a new generation of Florentine literates to revitalize Italian as a language of culture had grown in intensity and sophistication; a product of this environment was the Raccolta Aragonese, an anthology of Tuscan poetry delivered by Lorenzo de' Medici to Fredrick of Aragon, the King of Naples, around 1477. Latin, however, remained the essential language of intellectual exchange and it was part of humanistic debate along with its grammatical and syntactical rules. This is evident in a number of treatises that discuss the Latin language during the first half of the Quattrocento, the most important being by Lorenzo Valla, who, for instance in his Elegantiae linguae latinae - dated 1441 like Alberti's competition on vernacular poetry - endorses classical Latin as the first tool of thinking and writing for every kind of intellectual. Latin poetry had not died in Florence, and Braccesi was only one interlocutor of a complex network of humanists corresponding and exchanging Latin verses.

\footnotetext{
${ }^{56}$ Cracolici, Agiografie laiche, p. 106.

${ }^{57}$ Caciorgna 2005, pp. 154-157.
} 
In 1491, however, with his relocation to Siena, Braccesi's lyric poetry, both vernacular and Latin, was contaminated by a different tradition. Siena and her histories of illustrious women forge the homage to Camilla Saracina. Braccesi was clearly uncomfortable in choosing either vernacular or Latin, and could not make up his mind, using both and overlapping content that pertained to Florence, his hometown, and Siena, the place where he worked. The content of the carmen seems tightly linked to a Sienese approach to describing women by idealising their virtues and making them the icons of a whole city. Neoplatonic hints that belonged to Florence and the revival of Platonic philosophy were transferred into either the vernacular poems, or the paratext, i.e. the letters.

Despite the profound knowledge and curiosity that brought Braccesi to experiment all his life with his translations and renditions between Latin and vernacular, the small corpus dedicated to Camilla was not innovative enough to grant him the enduring memory among his peers that he had probably hoped for. Its multiple factors, however, paint a vivid picture of what diglossia culturally and linguistically entailed at this point of the fifteenth century.

\author{
Abbreviations \\ Catasto Florence, Archivio di Stato, Catasto. \\ L Florence, Biblioteca Medicea Laurenziana, Plut. 91 sup. 41 \\ SDO Florence, Archivio di Stato, Signori, Dieci di Balia, Otto di Pratica, Legazioni e \\ Commissarie Missive e Responsive.
}

\title{
Bibliography
}

Benedetto da Cingoli. Sonecti, barzelle, et capitoli del claro poeta B. Cingulo. Rome: per Johann Besicken, 1503.

Benedetto da Cingoli. Opere del preclarissimo poeta B. Cingulo novamente stampate. Con molte piu opere che non sono negli altri: cioe Sonetti. Barzellette. Capitoli. Siena: Simone Nardi and Giovanni Landi, 1511.

Braccesi, Alessandro. Carmina, ed. Alessandro Perosa. Florence: Bibliopolis, 1943.

Braccesi, Alessandro. Soneti e canzone, ed. Franca Magnani. Parma: Studium Parmense, 1983.

Ficino, Marsilio. El libro dell'amore, ed. Sandra Niccoli. Florence: Olschki, 1987.

Landino, Cristoforo. Carmina omnia, ed. Alessandro Perosa. Florence: Olschki, 1939.

Lapini, Bernardo. Vita di Madonna Onorata: scritta da Bernardo Ilicino, pubblicata per la prima volta sopra un codice del secolo 15 da Giuseppe Vallardi figlio. Milan: Giuseppe Bernardoni, 1843. 
Stabili, Francesco [Cecco d'Ascoli]. L'acerba: (Acerba etas), ed. Marco Albertazzi. Trento: La Finestra, 2002.

Agnoletti, Bice. Alessandro Braccesi: contributo alla storia dell'umanesimo e della poesia volgare. Florence: Passeri, 1901.

Barasch, Moshe. Blindness: the history of a mental image in western thought. New York: Routledge, 2001.

Battaglia, Salvatore. Grande dizionario della lingua italiana. Turin: UTET, 1961-2009, 24 vols.

Bellosi, Luciano, ed. Francesco di Giorgio Martino e il Rinascimento a Siena. Milan: Electa, 1993.

Bertolini, Lucia. "Latino-volgare e viceversa. Le traduzioni a Firenze fra XV e XVI" in N. Bianchi Bensimon, B. Darbord and M. Gomez-Géraud, eds., Le Choix du vulgaire: Espagne, France, Italie (XIIIe-XVIe siècle). Paris: Classiques Garnier, 2015, pp. 201-219.

Brown, Alison. Medicean and Savonarolan Florence: the interplay of politics, humanism, and religion. Turnhout: Brepols, 2011.

Caciorgna, Marilena. "Mortalis aemulor arte deos. Umanisti e arti figurative a Siena tra Pio II e Pio III" in Pio II e le arti: la riscoperta dell'antico da Federighi a Michelangelo, ed. Angelini A. Siena: Monte dei Paschi di Siena-Silvana Editoriale, 2005.

Carrai, Stefano. "Enea Silvio Piccolomini e la poesia senese" in S. Carrai, S. Cracolici and M. Marchi, eds, La letteratura a Siena nel Quattrocento. Pisa: ETS, 2009, pp. 31-42.

Carrai, Stefano. "Benedetto da Cingoli e la poesia a Siena nella seconda metà del Quattrocento" in S. Carrai, S. Cracolici and M. Marchi, eds, La letteratura a Siena nel Quattrocento. Pisa: ETS, 2009, pp. 43-52.

Carrai, Stefano, “Un commento quattrocentesco "ad usum mulieris": Jacopo de’ Buoninsegni sopra un sonetto del Cingoli” in S. Carrai, S. Cracolici and M. Marchi, eds, La letteratura a Siena nel Quattrocento. Pisa: ETS, 2009, pp. 53-72.

Catana, Leo. "Readings of Platonic virtue theories from the Middle Ages to the Renaissance: the case of Marsilio Ficino's De amore." British Journal for the History of Philosophy, vol. 22 (2014), pp. 680-703.

Ciociola Claudio, "Poesia gnomica, d'arte, di corte, allegorica e didattica" in Storia della letteratura italiana. eds Enrico Malato et al., 14 vols. Rome: Salerno, 1995-2005, vol. 2, pp. 327-454.

Cracolici, Stefano. "Agiografie laiche. Bemardo Ilicino e le donne illustri di Siena” in S. Carrai, S. Cracolici and M. Marchi, eds, La letteratura a Siena nel Quattrocento. Pisa: ETS, 2009, pp. 91-108. 
Cracolici, Stefano. "L'etopea di Ginevra, o il Somnium di Bemardo Ilicino" in S. Carrai, S. Cracolici and M. Marchi, eds, La letteratura a Siena nel Quattrocento. Pisa: ETS, 2009, pp. 109-134.

De Marinis, Tammaro and Perosa, Alessandro. Nuovi documenti per la storia del Rinascimento. Firenze: Olschki, 1970.

Isenberg, Nancy. "Censimento delle lettere di Niccolò Michelozzi". Giornale italiano di filologia, vol. 13 (1982), pp. 271-291.

Kristeller, Paul Oscar. "An Unknown Correspondence of Alessandro Braccesi with Niccolò Michelozzi, Naldo Naldi, Bartolommeo Scala, and other Humanists (1470-72) in Ms. Bodl. Auct. F. 2. 17" in Charles Handerson jr., ed., Classical Medieval and Renaissance Studies in Honor of Berthold Louis Ullman. Rome: Edizioni di storia e letteratura, 1964, 2 vols, vol. 2, pp. 311-359.

Martin Craig. Renaissance Meteorology: Pomponazzi to Descartes. Baltimore: Johns Hopkins University Press, 2011.

Orvieto, Paolo. "Un esperto orientalista del 400: Benedetto Dei." Rinascimento serie 2, vol. 9 (1969), pp. 205-275.

Perosa, Alessandro. "Braccesi, Alessandro" in Dizionario biografico degli italiani. Roma: Istituto della Enciclopedia italiana, 1960-[85] vols, vol. 13, 1971, pp. 602-608.

Perosa, Alessandro. "Storia di un libro di poesie latine dell'umanista fiorentino Alessandro Braccesi.” La bibliofilia, vol. 45 (1943), pp. 138-185.

Signoriello, Federica. Satire of Philosophy and Philosophers in Fifteenth Century Florence. London: University College London, 2014, doctoral thesis.

Viti, Paolo. "I volgarizzamenti di Alessandro Braccesi dell'Historia de duobus amantibus di Enea Silvio Piccolomini”, Esperienze letterarie, vol. 6 (1982), pp. 49-68.

Viti, Paolo. "Censimento delle lettere di Alessandro Braccesi." Archivio storico italiano 142 (1984), pp. $377-420$. 